\title{
Corrigendum
}

\section{CHAIN CONDITIONS ON SEMIRINGS}

T.K. MUKHERJEE, M.K. SEN and SHAMIK GHOSH

The following errors are corrected in the above paper which appeared in International Journal of Mathematics and Mathematical Sciences, Vol 19, No. 2 (1996) 321-326.

The following lines should be read as follows.

On page 325 , line 14 from the bottom:

We first show that the condition "unital" is not essential for one part of the result below.

THEOREM 2.6 Let $\mathrm{H}$ be a unital halfring Then ..

On page 325 , second line from the bottom:

THEOREM 2.8. Let $\mathrm{S}$ be a semiring with 1 . Then ... 


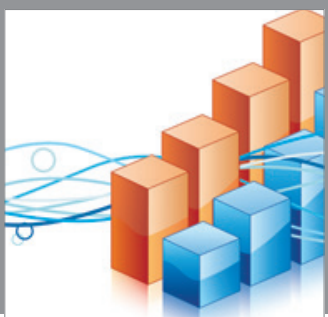

Advances in

Operations Research

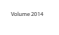

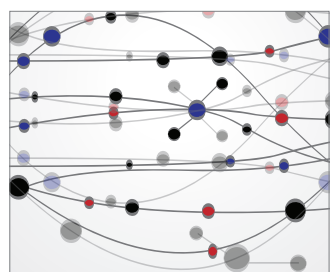

\section{The Scientific} World Journal
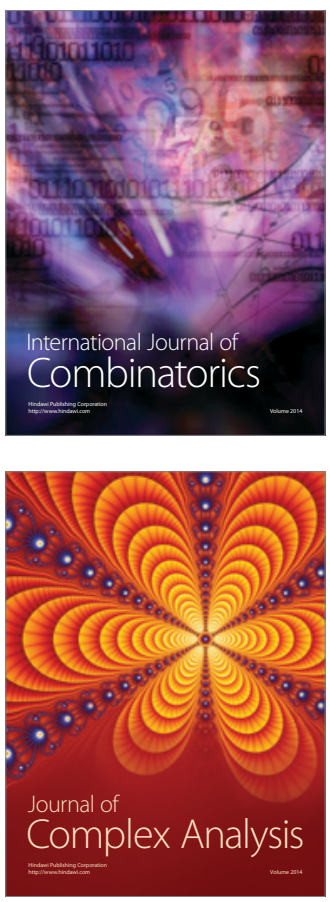

International Journal of

Mathematics and

Mathematical

Sciences
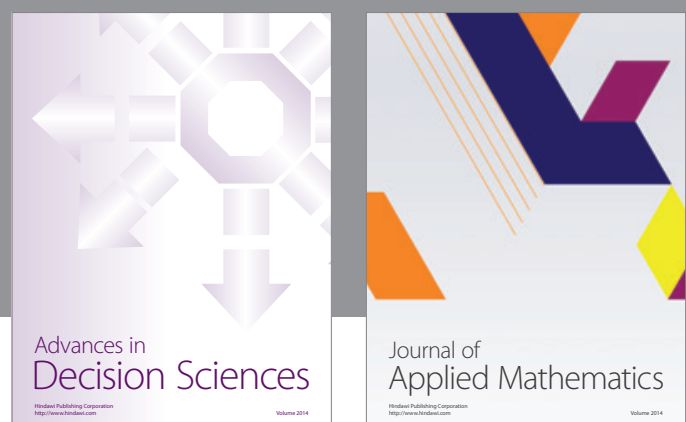

Journal of

Applied Mathematics
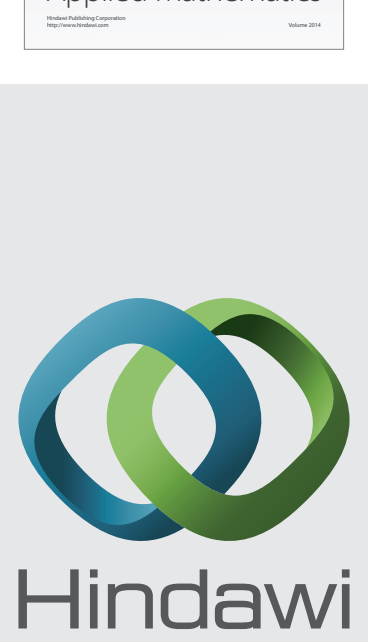

Submit your manuscripts at http://www.hindawi.com
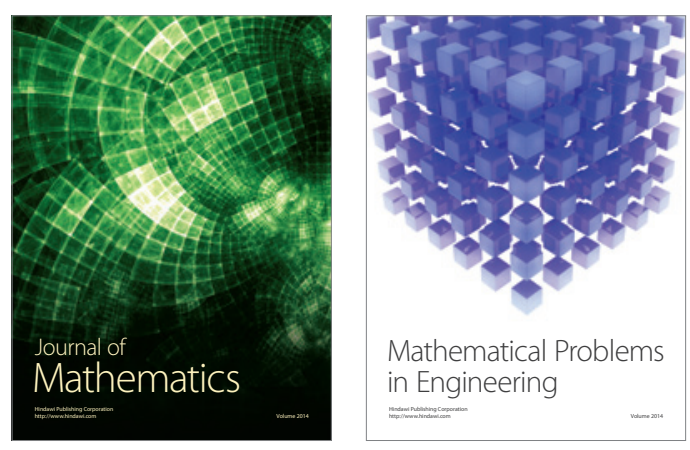

Mathematical Problems in Engineering
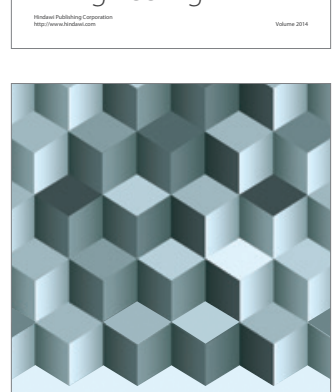

Journal of

Function Spaces
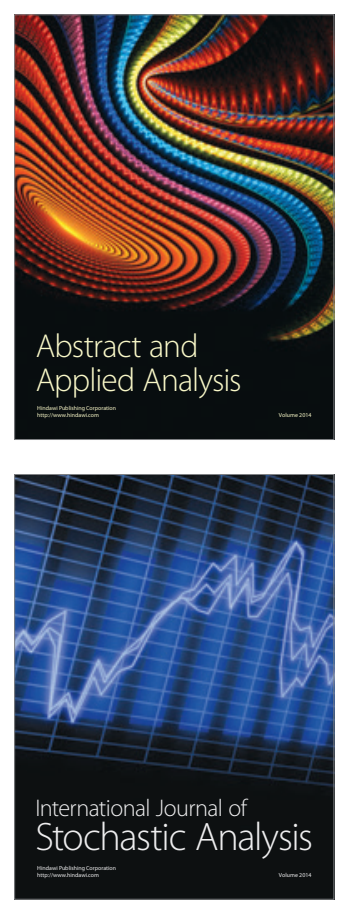

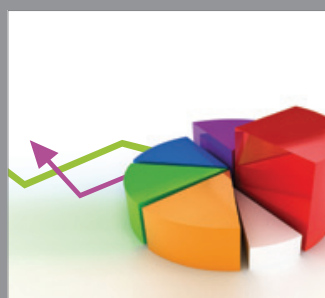

ournal of

Probability and Statistics

Promensencen
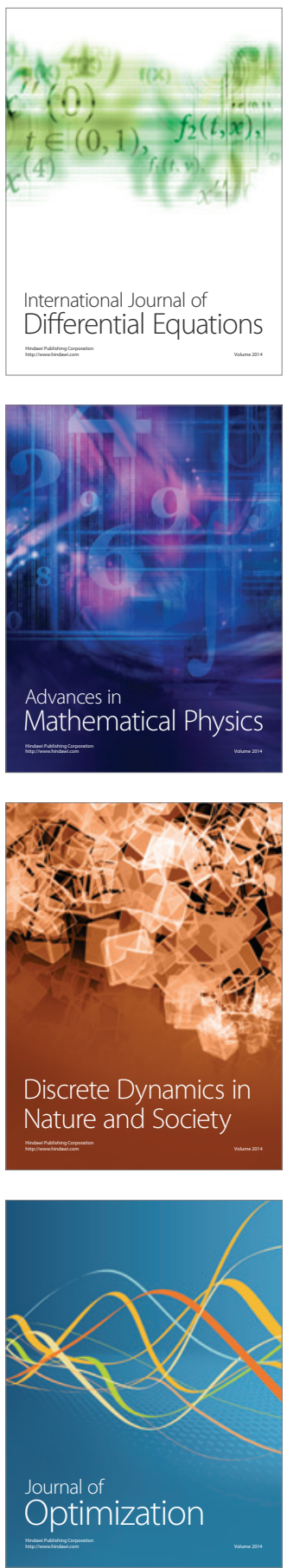